\title{
$82-189$
}

DCRL-S1921

\section{ESTIMATED REFRACTIVE INDEX AND SOLID DENSITY OF DT, WITH APPLICATION TO HOLLOW-MICROSPHERE}

\section{LASER TARGETS}

\author{
C. K. BrIggs \\ R. T. Tsugawa \\ C. D. Hendracks \\ P. C. Souers
}

September 16, 1975

Prepared for U.S. Energy Fiesearch \& Development

Administration under contract No. W-7405-Eng-48

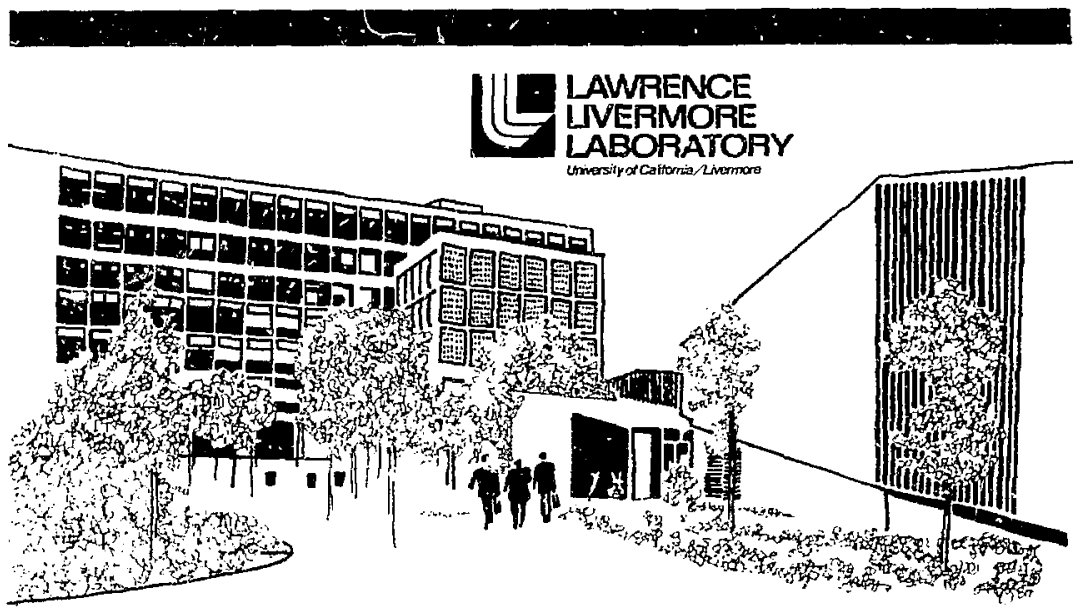


NOTICE

"This report was prepared as an account of work sponsored by the United Stotes Government. Neither the United Srates nou the Uniked States Energy Resetrch \& Development Administration, nor any of their emplayees, nor any of their contractors. cubcontractors, or their employes, makes any wartanty, express of implied, of assumes ony tegt tiability of responsibility for the aceuracy, completeness or uscfulncss of any information, apparatus, product of process disclased, of represents that lits use would not infsinge privately-owntd rights."

Printed in the United States of America Available from

National Technical Information Service U.S. Department of Commerce 5285 Por't Royal Road Springfield, Virginia 22151

Price: Printed Copy $\$ \_$; Microfiche $\$ 2.25$

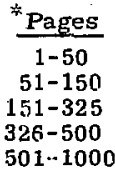

NTIS

Selling Price

$\$ 4.00$

$\$ 5.45$

$\$ 7.60$

$\$ 10.60$

$\$ 13.60$ 


\title{
近 \\ LAWRENCE UVERMORE LABORATORY \\ University of Caffornia, Livenmore, Calfornia, 94550
}

\section{UCRL-51921 \\ ESTIMATED REFRACTIVE INDEX AND SOLID DENSITY OF DT, WITH APPLICATION TO HOLLOW-MICROSPHERE LASER TARGETS}

\author{
C. K. Briggs \\ R. T. Tsugawa \\ C. D. Hendricks \\ D. C. Souers
}

MS. date: September 16, 1975

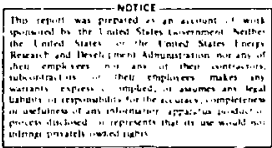




\section{Contents}

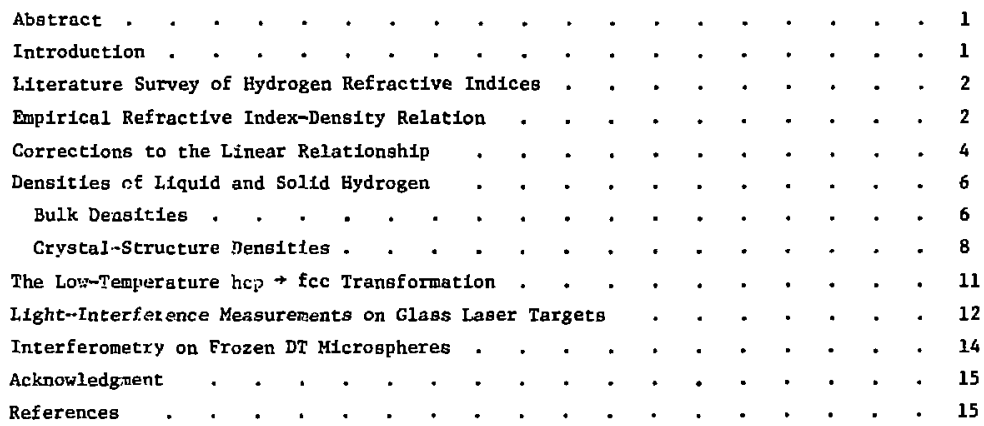




\title{
ESTLMATD REFRACTIVE INDEX \\ AND SOLID DENSITY OF DT, WTTH APPLICATION TO HOLLOW-MICROSPHERE LASER TARGETS
}

\author{
by \\ C. K. Briggs, R. T. Tnugawa. C. D. Hendricks \\ and P. C. Souers
}

\begin{abstract}
The literature values for the $0.55-\mathrm{jm}$ refractive Index $\mathrm{N}$ of 1 iquid and gasecus $\mathrm{H}_{2}$ and $\mathrm{D}_{2}$ are combined to yteld the equar tion

$(N-1)=\left[(3.15 \pm 0.12) \times 10^{-6}\right] \rho$,

where $;$ is the density in moles per cubic meter. This equation can be extrapolated to $300 \mathrm{~K}$ for use on DT in solid, Iiquid, and gas phases. The equation $t s$ based on a review of solid-hydrogen densities measured in bulk and also by diffraction methods. By extrapolation, the estimated densities and 0.55-um refractive indices for

DT are as follows:

\begin{tabular}{lccc}
\hline Stace & $T(K)$ & $\begin{array}{c}\text { Density } \\
\left(m o l e s / \mathrm{m}^{3}\right)\end{array}$ & $\begin{array}{c}\text { Refractive } \\
\text { 1ndex }\end{array}$ \\
\hline Solid & 4.2 & 0.053 & 1.17 \\
Solid & $19.71^{\mathrm{a}}$ & 0.051 & 1.16 \\
Liquid & $19.71^{4}$ & 0.0446 & 1.24 \\
\hline
\end{tabular}

${ }^{a_{T r}}$ ple point.

Radiation-1nduced point defects could posstbly cause optical absorption and a resultirg increased refractive index in solld DT and $\mathrm{T}_{2}$, The effect of the DT refractive index in measuring glass and cryogenle DT laser targets is also deecribed.
\end{abstract}

\section{Introduction}

A putistble source of energy in the twenty-ior it century is laser-induced hydrugen tusion. ${ }^{1-3}$ The experjtmental laser tirgets that are currently in ust are hollow glass microspheres fllled with DT Has, ${ }^{4-6}$ whereds ruture lasir targets are expected to be either liquid or solid mlirusplierus- first hollow and ultimacely solid--of IT Itself. hecause the basic method of inspecting transparent laser targets is optical, the refractive index of hydrogen will be of continuing importance. In anticipation of cryogenic targets, we are Inttiating an experimentel program on the properties of cryogenic UT. We are also reviewing a number of toptes of current interest in the area of cryogenic hydrogen, $7-9$ 


\title{
Literature Survey of Hỵdrogen
}

\section{Refractive Indices}

The Ifterature data are Iargely derived farom two papers, 10,11 whish are party summarlzed in the National Bureau of Standards cryogenic review. ${ }^{12}$ The first paper ${ }^{10}$ reports measurements of the refractive index of gaseous and lituid $\mathrm{H}_{2}$ at $0.5462 \mathrm{\mu m}$ by $1 \mathrm{n}-$ terferometry at temperatures of between 15 and $298 \mathrm{~K}$ and at pressures of up to $23 \mathrm{MPa}$. The second paper ${ }^{12}$ concerns data for 11quid $D_{2}$ (assumed norwal*) at $0.5461 \mu \mathrm{m}$ obtalned by computations based an earlite refractive Index ${ }^{12,13}$ and densily data. 12,14 Estimated 11 quid $D_{2}$ values at temptratures from 18.7 to $30 \mathrm{~K}$ are also glven for twe other wavelengths: $0.3200: . t$, for which $(N-1)$ 1s $5.4 \%$ higher than at $0.5461 \mathrm{im}$, and $0.6328 \mathrm{Lm}$, for which $(x-1)$ is $0.7 \%$ lower. 11 Several other sources of daca also exist. ${ }^{15-17}$ We have found no data on soldd hydrogen in the literature.

\section{Empirical Refractive Index-Density Relution}

Most estimates of the refractive Index are based on the Lorentz-Lorenz function, 18 which, however, is extremely sensitive to errors of measurement. Instead, we plot in Fig. 1 the refractive 1ndex of $\mathrm{i}_{2}$ and $\mathrm{v}_{2}$ at 0.55 um as a function of density in moles

\author{
per cubic meter. We find an essentially \\ Iinear relationship over the temperature \\ range 15 to $298 \mathrm{~K}$ and for both gas and $11 \mathrm{q}^{-}$ \\ uld phases. \\ The further generality of this refrac** \\ tive Index-density relationship, at least
}

\begin{abstract}
*Symmetr1c (sym or para) $\mathrm{H}_{2}$ has $100 \%$ of its molecules in even-numbered rotational levels. At low temperaturea, sym- $\mathrm{H}_{2}$ is the natural form and occupies the $\mathrm{J}=0$ rotatinnal level, where $\mathrm{J}$ is the rotational quantum number. If sym- $\mathrm{H}_{2}$ is brought quickly to room temperature, molecular symetry allows only fast $\Delta \vec{J}=+2$ transtitons, and the symetric $J=2$ level will be partly occupied. Over a period of weeks, forbidien $\Delta J= \pm I$ ransitions will occur, causing popuiation of the antisymmetric (asym) $\mathrm{J}=1$ and $\mathrm{J}=3 \mathrm{jevels}$. Normal hydrogen ( $\mathrm{nh}_{2}$ ) is the room-temperature equilibrium mixture with a population of $25.1 \%$ sym (even-numbered $\mathrm{J}$ ) and $74.9 \%$ asym (odd-J). The $\mathrm{D}_{2}$ mentioned above 15 assumed

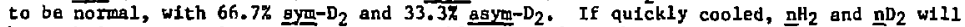
have their asymetric compconents metastably trapped in the $\mathrm{J}=1$ levels.
\end{abstract}

The term "equilibrium" (e) refers to the equilibrated sys-asym mixture at any temperature other than room temperature. The spectes HD, DT, and HT are expected to equilibrate quickly by $\Delta J=+1$ transizions allowed in molecular hydrogen with mixed isotopes. The specles $\mathrm{T}_{2}, \mathrm{DT}$, and $\mathrm{HT}$ are expected to also equilibrate quickly (e.8*, an hour) due to the catalyzing effects of the tritiun $E$ particle. 8,9

Solid hydrogen 18 unusual in that the di-atomic molecules are scarcely affected by the cryatal fields, and J remains a good quantum number. 


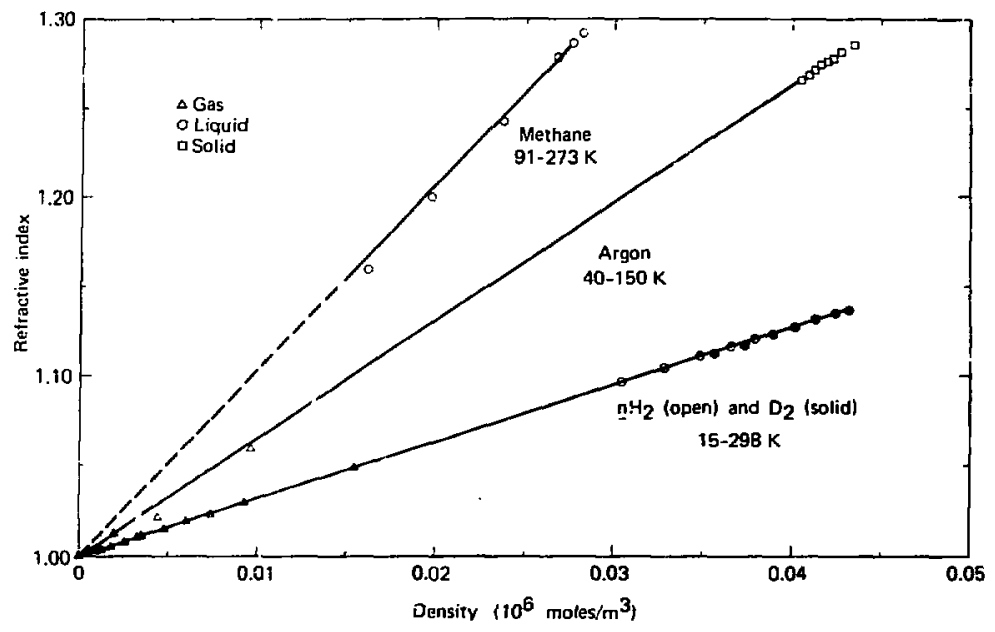

F1g. 1. Refractive Index vs, densfty for methane, argon, $\underline{n H}_{2}$, and $\mathrm{D}_{2}$.

for simple compounde, is shown by additiunal points in Fig. 1 for argon and methane, which can be summartzed as follows:

\begin{tabular}{|c|c|c|c|}
\hline Species & State & $\mathrm{T}(\mathrm{K})$ & $\begin{array}{c}\text { Wavelength } \\
\text { (1m) }\end{array}$ \\
\hline Argon 19 & Ges & $125-150$ & 0.5893 \\
\hline Argon $^{19}$ & Liqu Id & $86-145$ & 0.5893 \\
\hline $\operatorname{Argon}^{20,21}$ & Soltd & $40-84$ & 0.5893 \\
\hline Methane 22 & $\mathrm{Geg}^{\mathrm{a}}$ & 298 & 0.5462 \\
\hline Methane 19 & Liquid & $91-185$ & 0.5893 \\
\hline
\end{tabular}

At a piesoure of $0.1 \mathrm{MPa}$.

Figure 1 yielda a second bonus, It abpears that the $H_{2}$ and $D_{2}$ deta fall on the sane line. We shall analyze this more closely below, but we can Immediately pos- tulate a simple equation for all hydrogen 1sotopes, at any temperature, and for any phese:

$$
(N-1)=A^{\prime} O
$$

$A^{\prime}=(3.15 \pm 0.12) \times 10^{-6} \mathrm{~m}^{3} /$ mole,

where $N$ ts the Iefractive Index at 0.55 um and $p$ is the density in moles per cubic weter. Calculation sith this equation give refractive indices for 11 quid $\mathrm{H}_{2}$ that are $1.4 \%$ low and for gaseous $\mathrm{H}_{2}$ that are 1\% high.

From the data presented later, we est1mace an error bar of $\$ 4 \%$ for $(N-1)$ in covering all the hydrogen isotopes. 


\section{Corretions to the Linear Relationship}

The felationship of refractive Index and density may not be exactiy linear. The accuracy of measurements is difficult to decemine but may be considered as \pm 0.1 to $0.2 \%)$ fur $(N-1)$ and $\pm(0.1$ to $0.5 \%)$ for denstcy. $\therefore 0$ This leads to accuracy est1wates of $\pm(0.2$ to $1 x)$ for the I1near coef fiefent in Eq. (1).

We have attempted to improve $\mathrm{Eq}$. (1) by determining two virial coefficients. The first step in accorplishing this is to calculace the coefficient $A^{\circ} \mid(N-1)$ ! all $\mathrm{H}_{2}$ and $\mathrm{D}_{2}$ data, distinguishing between 11quid and gas, and between syp and normal states. The results are shown in Fig. 2 . We may imediately distingufoh two $\mathrm{H}_{2}$ gas Ines, ore for 30 to $100 \mathrm{k}$ and the other

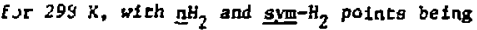
Indisingulshable. He now expand Eq. (1) to Include a second virtal coefeiclent,

$$
A^{\prime}=A+B \rho,
$$

where $A^{\prime}$ is defined as (N - 1)/F in Eq. (1) and $p$ is the density in moles per cubtc meter. Fror F1g. 2, we obtain the followIng coefficlents for $\mathrm{H}_{2}$ gas:

\begin{tabular}{lll}
\hline (K) & $A\left(\mathrm{~m}^{3} / \mathrm{mole}\right)$ & $\mathrm{B}\left[\left(\mathrm{m}^{3} / \mathrm{mole}\right)^{2} \mathrm{j}\right.$ \\
\hline $30-100$ & $3.116 \times 10^{-6}$ & $1.857 \times 10^{-12}$ \\
298 & $3.127 \times 10^{-6}$ & $1.534 \times 10^{-12}$ \\
\hline
\end{tabular}

ting values for $\mathrm{H}_{2}$. The slope $\mathrm{B}$ remains about the same, tut the intercept $A$ is $0.329 \mathrm{~m}^{3} /$ mole lower for I'? than for $\mathrm{H}_{2}$. For cold $T_{2}$ gas, we extrapolate an A value of $3.040 \times 10^{-6} \mathrm{~m}^{3} / \mathrm{mole}$, which yields an expected refractive index about 3 : ivicis than the value generaced by Eo. (1). Hence we have given a $\pm 4 \%$ spread to Eq. (1).

The data for the liquld are not so well behaved. Figure 3 shows the soeffteient $\lambda$ as a function of temperature for the liquelds sym- $\mathrm{H}_{2}$, $\mathrm{nll}_{2}$, and $\mathrm{D}_{2}$ iassumed normal). The sum- $\mathrm{H}_{2}$ data show a strange droj. near the crieical potnt, whis: has not bee: explained as yet. Again, the values are lower for $\mathrm{D}_{2}$ than for $\mathrm{H}_{2}$. he roughly extrapolate the data for higher mass ans to lower temperacures to obtain

LIquid :

$A^{\prime}=\left(3.190-0.0175(x-2) ; 10^{-6} \mathrm{f}^{3}\right.$ mole.

Solfd:

$A^{\prime}=[3.195-0.015(\mathrm{M}-2)\} \times 10^{-6} \mathrm{~m}^{3} / \mathrm{mole}$.

Here $M$ is the molecular weight of the approprlate hydrogen spectes (to the negres: Integer). 


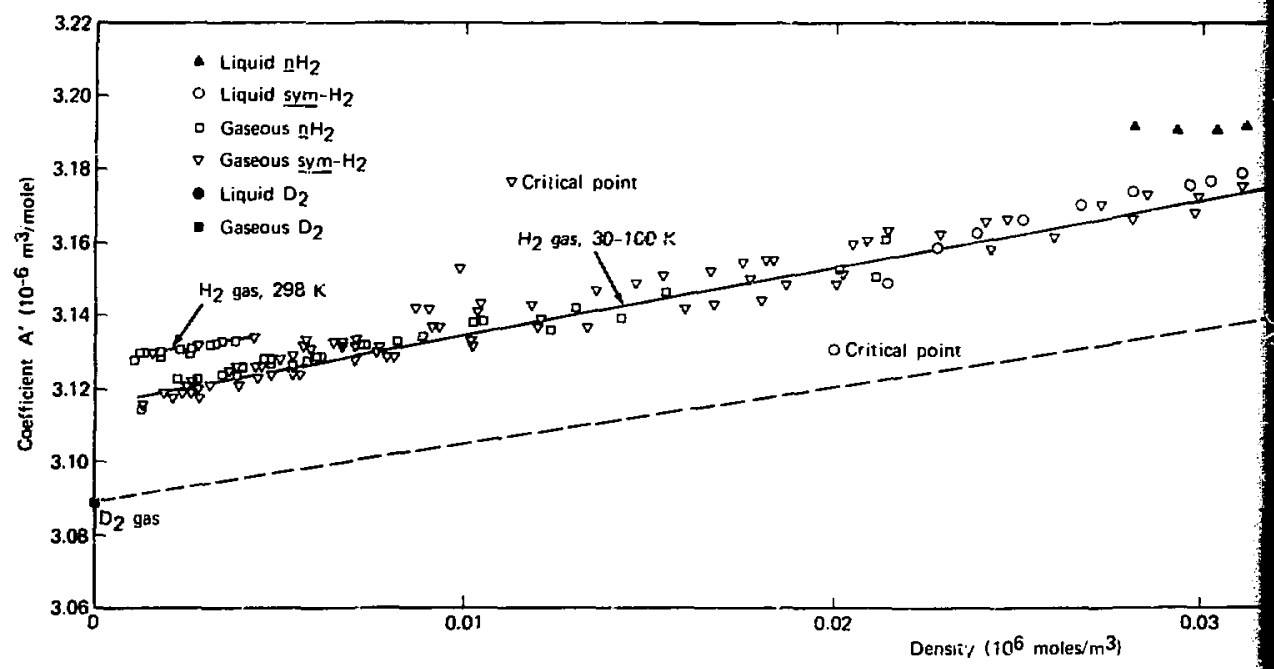





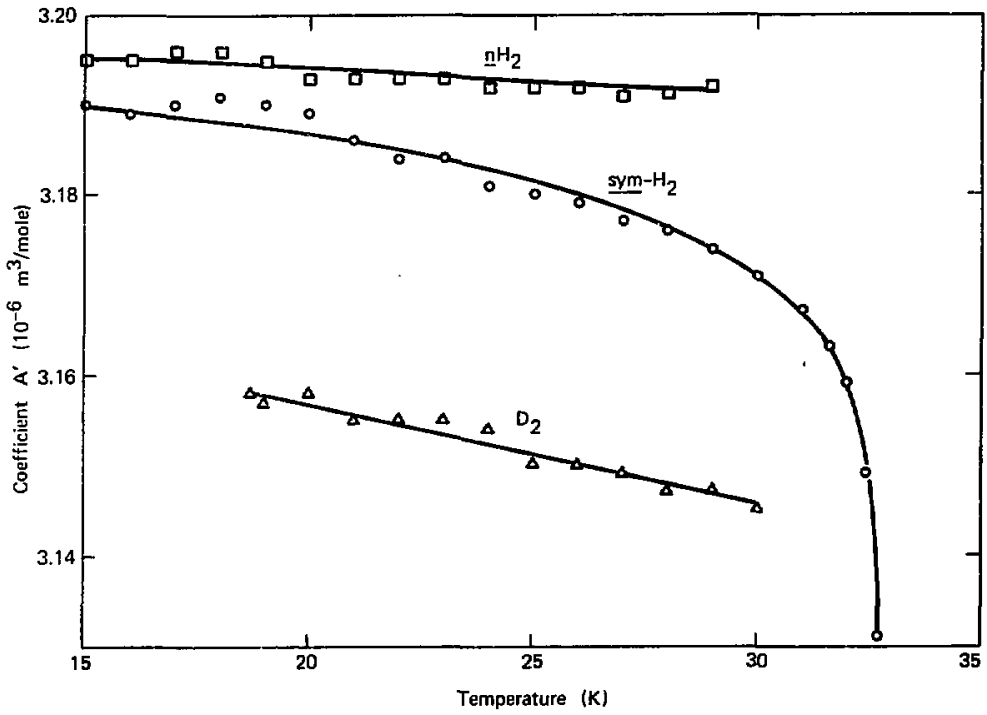

F1g. 3. Coefficient $A^{\prime}$ as a function of temperature for sym- $\mathrm{H}_{2}$, $\underline{\mathrm{nH}}_{2}$, and $\mathrm{D}_{2}$.

\section{Densities of Liquid and Solid Hydrogen}

The 11quid densities for the hydrogens from the triple points to $25 \mathrm{~K}$ can be taken from a previous compilation. 9 The data are shown in Fig. 4 and Table 1.

It now remains to consider the literature data for solid hydrogen, which forms In a hexagonal close-packed (hcp) structure on freezing at the triple point. ${ }^{24}$ Density deturminations have been made primarily by two methods: bulk densities reported as molar volumes, and densities determined from diffraction measurements of crystal structure. The' s cwo methods are reviewed separately in this report.
BULK DENSITIES

Four separate stud 1es have been carried out. $^{24-28}$ The most basic approach was taken by Megaw, who f1rst measured solid $H_{2}$ and $D_{2}$ densities in 1939. She filled a known volume with solid hydrogen and measured the amount $1 \cdot y$ subliming to a PVT apparatus. The technique was cross-checked with solid helium of known density. ${ }^{25}$ The other major approach to this measurement 13 to determine the phase diagram and latent heat of fusion and then calculate the volume change on freezing by the clarsiusClapeyron equation. ${ }^{26,29}$ From a knowledge 


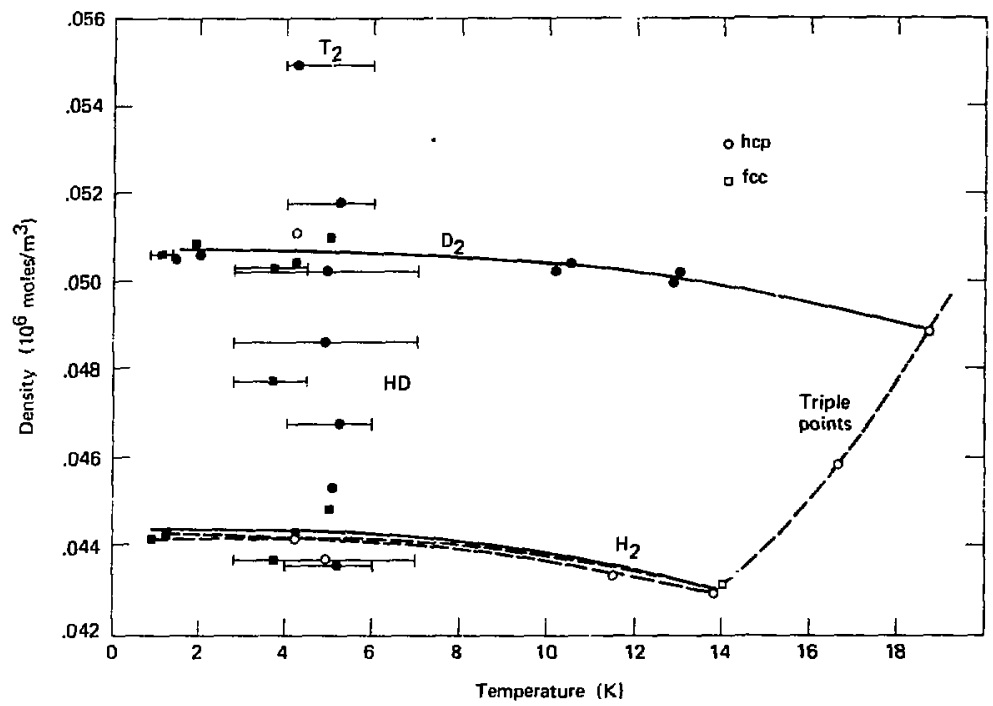

Fig. 4. Densitles of the hydrogen 1sotopes in the solid state as a function of temperature. The open ayaboly represent data obtained in bulk deterininations; the oolid symbols are points for data obtained in crystal-structure determinations.

Table 1. Lattice parameters of solid hydrogen.

\begin{tabular}{|c|c|c|c|c|c|c|}
\hline \multirow[b]{2}{*}{ Spectes } & \multicolumn{3}{|c|}{ hcp } & \multirow{2}{*}{$\frac{\text { fcc: }}{a}$} & \multirow{2}{*}{$\begin{array}{l}\text { Diffraction } \\
\text { method }\end{array}$} & \multirow[b]{2}{*}{ Reference } \\
\hline & $\mathbf{a}$ & c & $c / a$ & & & \\
\hline $\mathrm{H}_{2}$ & 3.76 & 6.11 & 1.62 & 5.31 & $x-$ ray & $32^{b}$ \\
\hline $\mathrm{HD}$ & $\begin{array}{l}3.68 \\
3.64\end{array}$ & $\begin{array}{l}6.06 \\
5.95\end{array}$ & $\begin{array}{l}1.66 \\
1.63\end{array}$ & 5.18 & $\begin{array}{l}\text { x-ray } \\
\text { Electron }\end{array}$ & $\begin{array}{l}31 \\
34\end{array}$ \\
\hline$D_{2}$ & $3.59-3.62$ & $5.83-5.88$ & $1.61-1.64$ & $5.07-5.08$ & $\begin{array}{l}x \text {-ray } \\
\text { Neutron }\end{array}$ & $38^{b}, 37^{b}$ \\
\hline $\mathrm{T}_{2}$ & 3.47 & 5.80 & 1.67 & -- & $x-$ ray & 31,40 \\
\hline
\end{tabular}

${ }^{a}$ Latilce parameters in angstroms.

${ }^{b}$ Considered best data. 
of the densicy of the liquid, the corresponding denstty of the solld may be calculated.

Bulk-density data are avallable for $\mathrm{H}_{2}$ at $4.2 \mathrm{k}^{25}$ and at the triple point, ${ }^{26}$ for HD at the triple point, ${ }^{26}$ and for $b_{2}$ at $4.2 x^{25}$ and at the triple point. 26

\section{CRYSTAL-STRUCTURE DENSITIES}

Much work has been done in this fleld In studylng the transition from hexagonal cloge-packed structure to face-centered cub1c structure (hep $\rightarrow$ fcc) that tekes place as solid hydrogen is cooled to 2 to $4 \mathrm{k}$. The transition is flrst arder, but the volume change $1 s^{30}$ only $0.5 \%$, and the densities of the two phases are 1nterchangeable within experimental error. The gyw-asym ratios also appear to have no measurable effect on density.

The methods used include $x-r a y$, electron, and neutron diffraction. The phases have been studied at the nominal temperatures listed below.

\begin{tabular}{cccccc}
\hline & \multicolumn{2}{c}{ hcp structure } & \multicolumn{2}{c}{ fcc structure } \\
\cline { 2 - 3 } \cline { 5 - 6 } Species & $\mathrm{T}(\mathrm{K})$ & Rei. & & \multicolumn{1}{c}{$\mathrm{T}(\mathrm{K})$} & Ref. \\
\hline $\mathrm{H}_{2}$ & $1.3-7$ & $31-36$ & & $0.9-5$ & $32-36$ \\
$\mathrm{AD}$ & $2.8-7$ & 31,34 & & $2.8-4.5$ & 34 \\
$\mathrm{D}_{2}$ & $1.4-13$ & $31,34-39$ & $1-5$ & 33,35, \\
$\mathrm{~T}_{2}$ & 4.2 & 31,40 & & - & - \\
\hline
\end{tabular}

The best data, In our optnion, come from certain of the $x$-ray diffraction 32,38 and neutron-diffraction data ${ }^{37,39}$ and cover only $\mathrm{H}_{2}$ and $\mathrm{D}_{2}$, The Iange of latt1ce parameters for both erystal structures is shom in Table $I$. The hep structure cor- responds almost exactly to the elassical close packing of spheres, witich has a $\mathrm{c} / \mathrm{a}$ racio $^{41}$ of 1,633 . The denstes may be calculated frot the lattice parameters, recalling that the hep structure ha: two lattice points per cel1 41 and the fcc structure has four. 42

All the bulk and crystal structure densitier described above are now combined as a function of temperature In FIs - 4. Many of the cryatal structure polnts have conslderable error bsrs of temperature uncertainty. The two broken $\mathrm{H}_{2}$ 1Ines represent the results of two thermodynamic theorles, and the agreement is quite good. 43,44

We have dertved emptrical formulas for the data of FIg. 4, The curvature of the $D_{2}$ data requires the empirical form

$$
\rho=\rho_{0}-C T^{3},
$$

where $p$ is the golid density in moleg per cuble meter, $P_{0}$ the density at $0 \mathrm{~K}, \mathrm{~T}$ is che cemperature, and $G$ is a constant. The solid IInes for $H_{2}$ and $D_{2}$ In FIg. 4 are the easilg derived forms for Eq. (6). The coefficients $\rho_{0}$ and $C$ are listed for $A_{2}$ and $\mathrm{D}_{2}$ In Table 2 wth the densities at $4.2 \mathrm{~K}$ and at the triple point. For $\mathrm{HD}$, however, only data at the triple point are usable; the scatter at low temperatures makes eatimation of $\rho_{0}$ 1mpossible. 1f we Interpolate between the values of $\rho_{0}$ and $c$ for $\mathrm{H}_{2}$ and $\mathrm{D}_{2}$, we obtaln a fit that $\mathrm{ts}$ quite reasonable.

For heavier molecules than $\mathrm{D}_{2}$, however, the uncertainties become extreme. There Is only one point for $T_{2}$ at $4.2 \mathrm{~K}$, with a posalble temperature uncertafnty of 2 degrees above 11qufd hellum temperatures. 
Table 2. Densities and refractfve indices of liquid and solid hydragen. ${ }^{a, b}$

\begin{tabular}{|c|c|c|c|c|c|c|c|c|c|}
\hline \multirow[b]{2}{*}{ Spec1es } & \multirow[b]{2}{*}{$\begin{array}{l}\text { Triple } \\
\text { polnt } \\
\text { (K) }\end{array}$} & \multirow[b]{2}{*}{$\begin{array}{c}\text { Constant } \\
C \\
\left(\times 10^{-7}\right)\end{array}$} & \multicolumn{4}{|c|}{ Density $\left(10^{6}\right.$ moles: $\left./ \mathrm{m}^{3}\right)$} & \multicolumn{3}{|c|}{ Refractive index at $0.55 \mathrm{Hm}$} \\
\hline & & & $\begin{array}{l}\text { Solfd, } \\
0 \mathrm{~K}, \rho_{0}\end{array}$ & $\begin{array}{l}\text { Sol1d, } \\
4.2 \mathrm{~K}\end{array}$ & $\begin{array}{l}\text { Solid, } \\
\text { triple } \\
\text { point }\end{array}$ & $\begin{array}{l}\text { Liquid, } \\
\text { triple } \\
\text { pontet }\end{array}$ & $\begin{array}{l}\text { Solid, } \\
4.2 \mathrm{~K}\end{array}$ & $\begin{array}{l}\text { Solid, } \\
\text { eriple } \\
\text { point }\end{array}$ & $\begin{array}{l}\text { Liquid, } \\
\text { criple } \\
\text { point }\end{array}$ \\
\hline $\begin{array}{l}\mathrm{J}=\mathrm{OH} \mathrm{H}_{2} \\
\underline{\mathrm{nH}}_{2}\end{array}$ & $\begin{array}{l}13.803 \\
13.957\end{array}$ & 4.78 & $(0.0443)$ & 0.0443 & $\begin{array}{l}0.04291 \\
0.04301\end{array}$ & $\begin{array}{l}0.03821 \\
0.03830\end{array}$ & $(1.142)$ & $\begin{array}{l}(1.137) \\
(1.137)\end{array}$ & $\begin{array}{l}1.122 \\
1.122\end{array}$ \\
\hline HD & 16,604 & $(3.84)$ & $(0.0476)$ & 0.048 & 0.04579 & 0.04062 & $(1.15)$ & $(1.146)$ & $(2.129)$ \\
\hline $\begin{array}{l}\mathrm{J}=O \mathrm{D}_{2} \\
\mathrm{nD}_{2}\end{array}$ & $\begin{array}{l}18,691 \\
18,71\end{array}$ & 2.40 & $(0.0507)$ & 0.0507 & $\begin{array}{l}0.04859 \\
0.04883\end{array}$ & $\begin{array}{l}0.04299 \\
0.04317\end{array}$ & $(1.160)$ & $\begin{array}{l}(1.154) \\
(1.155)\end{array}$ & $\begin{array}{c}(1.136) \\
1.136\end{array}$ \\
\hline DT & $(19,71)$ & $(2.5)$ & $(0.053)$ & $(0.053)$ & $(0.051)$ & $(0.0446)$ & $(1,17)$ & $(1.16)$ & $(1,140)$ \\
\hline$\underline{e} \underline{T}_{2}$ & 20.62 & $(2.4)$ & $(0.055)$ & $(0.055)$ & $(0.053)$ & 0.04539 & $(1.17)$ & $(1.17)$ & (1.142) \\
\hline
\end{tabular}

Data from Refs, 31 and 45 ,

bstimated values are shown in parentheses.

Even so, the density of $0.0549 \times 10^{6}$ moles/ $\mathrm{m}^{3}$ seems high.* Solid $\mathrm{T}_{2}$ must efther shrink more than $D_{2}$ on warming to the triple polnt (1.e., musc have a larger value of $C$ ) or nust exhibit a large shrinkage on freezing. We have taken a $p_{0}$ value of $0.055 \times 10^{6} \mathrm{moles} / \mathrm{m}^{3}$ for $\mathrm{T}_{2}$, essentially the $4.2 \mathrm{~K}$ value, and estrmated a $\mathrm{C}$ value of $(2.4 \pm 1.4) \times 10^{-7}$ mole/m $\mathrm{m}^{3}-k$, jugt below that of $\mathrm{D}_{2}$. This ylelds an estimated densicy at the triple point of $0.053 \pm$ $0.001) \times 10^{6}$ moles $/ \mathrm{m}^{3}$. Th1s large uncertainty is also show by the error bar for the molar volume of the solid at the triple point for $I_{2}$, Once $\rho_{0}$ and $C$ values are es-

*Th1s value is obtalned from the hep x-ray lattice parameters. 31 However, the previous Soviet value of $0.0537 \times 10^{6}$ moles/ $\mathrm{m}^{3}$, which was erroneously derived for an assumed tetragonal structure, 40 has been cited in NBS-641.45 This value leads \pm 0 a freezing shrinkage volume more in ine with the lower-mass hydrogen 1sotopes, but we report the Soviet data in the form the researchers considered to be final. t1mated, corresponding values are obtalned for DT by interpolation. These are lisced In Table 2.

By using Eq. (6) plus the isotopic coefficients listed in Table 2, we can estimace the solld densities from $0 \mathrm{~K}$ to the triple point. These estimates are good for efther the hcp or fcc structures and for any sym-asym mixture, because small changes are aubmerged in the errors of ebtimation. The resulting solid and liquid densicles at $4.2 \mathrm{~K}$ and the triple points are also listed in Table 2.

Once densities axe known, the refractive indices of liquid and solid hydrogen can be calculated from Eqa. (1), (4), and (5). The resulting refractive indices at $4.2 \mathrm{~K}$ and at the triple points are listed in Table 2. The refractive indices of the solids assume no new effects due to the radiation from the tritium. RadiationInduced point defects, however, could concelvably cause absorption and an increased refractive index in the visible portion of 
Table 3. Spectflc volumes and freezing shrlnkages for 1 iquid and solid hydrugen. 1 ,b

\begin{tabular}{|c|c|c|c|c|c|c|c|}
\hline \multirow[b]{2}{*}{ Species } & \multirow[b]{2}{*}{$\begin{array}{l}\text { Molecular } \\
\text { welght } \\
\text { (g/mole) }\end{array}$} & \multirow[b]{2}{*}{$\begin{array}{l}\text { Triple } \\
\text { point } \\
\text { (K) }\end{array}$} & \multicolumn{4}{|c|}{ Spectfic volume $\left(10^{-6} \mathrm{~m}^{3} / \mathrm{mole}\right)$} & \multirow[b]{2}{*}{$\begin{array}{c}\text { Freszing } \\
\text { shrinkage } \\
\text { (\$) }\end{array}$} \\
\hline & & & $\begin{array}{c}\text { Solid, } \\
0 \mathrm{~K}\end{array}$ & $\begin{array}{l}\text { Solid, } \\
\text { triple } \\
\text { point }\end{array}$ & $\begin{array}{l}\text { Liquid, } \\
\text { eriple } \\
\text { point }\end{array}$ & $\begin{array}{l}\text { Freezing } \\
\text { shrinkage } \\
\text { volume }\end{array}$ & \\
\hline \multirow{2}{*}{$\begin{array}{l}\mathrm{J}=\mathrm{OH} \mathrm{H}_{2} \\
\mathrm{nH}_{2}\end{array}$} & \multirow{2}{*}{2.016} & 13.803 & \multirow{2}{*}{$(22,57)$} & 23.30 & 26.173 & -2.873 & -11.0 \\
\hline & & 13.957 & & 23.25 & 26.108 & -2.858 & -11.0 \\
\hline $\mathrm{HD}$ & 3.023 & 16.604 & $(21,03)$ & 21.84 & 24.62 & -2.78 & -11.3 \\
\hline \multirow{2}{*}{$\begin{array}{l}J=0 D_{2} \\
\mathrm{nD}_{2}\end{array}$} & \multirow{2}{*}{4.029} & 28.691 & \multirow{2}{*}{$(19.72)$} & 20.58 & 23.262 & -2.682 & -11.5 \\
\hline & & 18.71 & & 20.48 & $23 \cdot 162$ & -2.682 & -11.6 \\
\hline DT & 5.032 & $(19.71)$ & $(18.8)$ & (19.5) & $(22.4)$ & $(-3.0)$ & $(-13)$ \\
\hline$\underline{\mathrm{e}} \mathrm{T}_{2}$ & 6.034 & 20.62 & $(18.2)$ & (18.9) & 22.03 & $(-3.1)$ & $(-14)$ \\
\hline
\end{tabular}

${ }^{a}$ Data from Refs. 31 and 45.

bst1maced values are shown in parentheses.

the spectrum. There is no way to eatimare such effects at this time. It appears important that an optical spectrum should be measured for DT to ascertain possible problems of laser 11ght absorption.

We now Invert the liquid and solld densities inco spectife volumes, which are listed for $4.2 \mathrm{~K}$ and the triple points in Table 3. The spectfic volumes at $\mathrm{O} K$ and at the triple points are also plotted in FIg. 5 as a function of molecular weight, so that the effect of 1ncreasing molecular weight way be observed. The experimental densities of Table 2 and specific volumes of Table 3 and Fig. 5 are the recently recomended values of the National Bureau of Stand ards. 45

Table 3 showg thet $H_{2}, H D$, and $D_{2}$ all contract about $11 \%$ with a sight increase with molecular wefght. However, estimated DT and $\mathrm{T}_{2}$ shrinkage values are approximately 13 and $14 \%$, respectively. This effect is also shown by the widening of the gap between the moler volumes of the solld

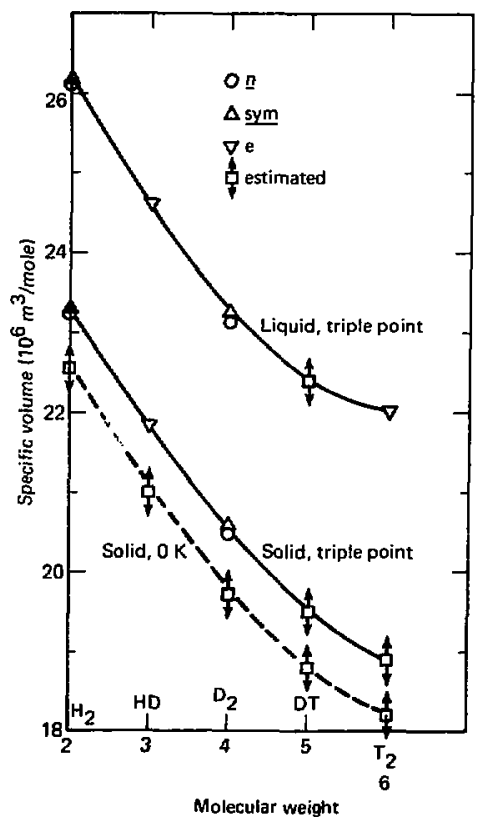

Fig. 5. Specific volumes of the 11quid and sol1d hydrogers. 
and the liquid at the triple point in Fig. 5. The larger shrinkage estimates are due solely to the single Soviet $T_{2}$ data point ${ }^{31}$ at $4.2 \mathrm{~K}$. It would be quite interesting to measure the DT and $T_{2}$ Ereezing shrinkage volumes to see if they are indeed larger than expected from the lighter hydrogen 1 sotopes.

The shrinkage is also quite important as regards laser-larget fabrication. It Is thought that hollow LT microspheres may be the targets at $10-\mathrm{kJ}$ laser energles. $1-3$ Recently, such shells of hollow $\mathrm{H}_{2}$ have been prepared by the Rayleigh liquid- jet method. 46 Such hollow liquid microspheres would be Injected into a vacuum for laser firfing. Sublination in the vacun would cause the microsphere to freeze from tha oulside in. The resulting shrinkage would set up strains that could conceivably shatter the frozen bubble. Since nucleation of the ireezing would probably not be symmetrical, the shrinkage aighe also cause considerable ilstortion of the symmetrical microsphere. For these reasons, the detalls of the $D_{1}^{T}$ freezing process w 11 be of great importance in laser-target fabrication.

\section{The Low-Temperature hep - fec Transformation}

Heat-capac1ty measurements on solid $\mathrm{H}_{2}$ and $\mathrm{D}_{2}$ show a component belo's $11 \mathrm{~K}$ that does not decline to zero according to the usual Debye curve. 47 This is due to the presence of the frozen-1n metastable $J=1$ species. When the $J=1$ species is more than $60 \%$ of the total, the heat capacity shows a spike In the vicinity of $2 \mathrm{~K}$, which was called, when first discovered, the $\lambda$ anomaly. 48

By 1968, a large amount of data could be correlated. The results of $x-r a y d 1 f-$ fraction measurements on bulk crystals show that the hcp structure of hydrogen formed at the triple point changes at the $>$ anomaly to $\mathrm{fcc}^{35,49}$ ThI occurs in $\mathrm{H}_{2}$ and $D_{2}$ only for $J=1$ greter than about 60\%. For $J=$ i less than $60 \%$, the hep structure remains ${ }^{5 j}$ to at least $0.2 \mathrm{~K}$. The phase transformation is first order, with a volume charge ${ }^{30}$ of $0.5 \%$. It demonatrates hysteresis, with the fec structure becoming more stahle with each thermal recycle, until heating to $22 \mathrm{~K}$ is required to fully reconstitute the hep structure. This hysteresis is greater for $\mathrm{D}_{2}$ than for $\mathrm{H}_{2}$ and 1ncreases as the $J * 1$ component increases toward 100\%. The transtelon temperature also increases linearly with the percent of the $J=1$ component, with extrapolated $100 \%$ values $^{35}$ being $2.8 \mathrm{~K}$ for $\mathrm{H}_{2}$ and $3.8 \mathrm{~K}$ for $D_{2}$. Suppcfting evidence for the phase transformation is also seen in the results of measurements by neutron diffraction, ${ }^{39}$ Infrared spectroscopy, ${ }^{51}$ and nuclear magnet ic resonance. 52

Electron-d1fifaction studies on 100- to 1000- $\AA$ fllms of solid hydrogen show, however, that the fcr forw 1 more easlly generatci in films than in bulk crystals. 33,34 Films of $\underline{\mathrm{nH}}_{2}, \mathrm{HD}$, and $\underline{\mathrm{nD}}_{2}$ first freeze on the substrates in hcp form with the c-axis perpendicular to the substrete surface. Conversion to the fce form occurs in the range 4.5 to $5 \mathrm{~K}$. The conversion of $\mathrm{HD}, 34$ surely a state where the $J \cdot 1$ spectes is close to zero, is quite unexpected. 
It has long been belleved that an orderIng of rotational moments is Involved in the $\lambda$ anomaly, although the actual physical arrangement 19 not well understood, The most picturesque analogy is to 1magine the $J=1$ rotational moments $11 n i n g$ up 1 an "antiferromagnet1c" structure. 53,54 A rotational moment moy flip, and the excitation may travel down the crystal lattice In a wavelike manner. Such an excitation is assumed to take and give energy in a quantized manner. It is called a "11bron," by direct analogy with spin-wave "magnons" In antfferromagnetic cryatals. For this reason, the fcc atructure is called the "ordered" atate of hydrogen, and the hep structure the "disordered."

It is thought that some degree of rotational-moment ordering may occur even in the hep forms that exist to $0.2 \mathrm{~K}$ when the $J$ - 1 species 18 less than 60\% in bulk samples. 55 As the percentage of the $\mathrm{J}=1$ apecles increases, the force for alignment Increases rapidly unt 11 the actual cryatal traneformetion occurs. ${ }^{35}$ Thin films may become ordered more easily because of the forces from the substrate and the sma11 amount of hydrogen to be rearranged. Several stuöles using Raman spectroscopy are currently under way In order to ascertain the true ordered structure by studying the 11brons. 56,57

The hep - fcc transformation does not appear to be of great 1mportance from an applied point of view. By extrapolating the $100 \% J=1$ transition temperatures for $H_{2}$ and $D_{2}$, one might expect a transformtion of bulk frozen DT and $T_{2}$ above $4.2 \mathrm{~K}$. It may even occur at higher temperatures for DT plated onto the sides of a glass microsphere, since this may approximate the thin-film behavior. However, the tritium $B$ particle 19 likely to catalyze rotational transitlono to the $J=0$ level in less than an hour. 58,59 The Low-temperature equilibrium mixture of $\mathrm{eD}_{2}-\mathrm{DT}-\mathrm{eT} \mathrm{T}_{2}$ will have a low percentage of $\mathrm{J}=1$ molecules to Induce ordering. Pechaps the only transformation property that wight affect lasertarget fabrication is the volume change, wich w11 place an additional stress on the frozen wicrosphere.

\section{Light-lnterference Measurements on Glass Laser Targets}

It has been mentioned that current laserfuston targets are glass microspheres that have been belected for unfform wall thickneas by $11 \mathrm{ght}$ interference ${ }^{4-6}$ and fllled with DT. The circular fringes may be analyzed by a refractive ray-trace progran that ylelds the averabe wall thickness, provided the refractive Index of the glass $1 \mathrm{~s}$ known. Stone showed that wuch wall-chickness measuramente are beavily influenced by the refractive index of 'in DT fill gas inside the microsphere. ${ }^{60}$ Weinstein has devised an Improved wall-thickness measurement method, employing white light, that also depends on knowing the refractive Index of DT gas. 61

The full refractive ray-trace program 5,62 is too complex to present here, but a simple theory serves to show the physical principles Involved.

The interferometer is composed of a reference arm and the sample arm contalning the hollow glass microsphere. A light bear is 
split inte two parts, one entering each irth. The beans in each ara travel almost identical pach lengths (Including reflection at 1dentical mirrors), reconverge, and interEere. Microscope lenses are included in each interferometer arm since laser targets are only 50 co 100 jin in diameter.

A schematic for the simple light interference model is shown in Fig, 6. All

lengths are dimensionless, having been divided by the true outer radius $r_{1}$. The ray in FIg. 6 procieeds from left to right, is reflected at the nifror, and returns. The index of refraction 151.000 for the a1r, $N^{*}$ for the microsphere glass, and $N "$ far the $D T$ gas Inside the microsphere. Other lengths, In dimensionless units, are $P$, the planar radius to an irbitrary ray; $l$, the wall thickness; and ( 1 - L), the Inner radius.

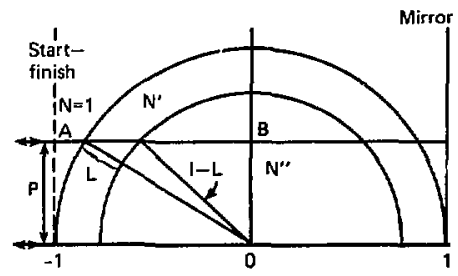

Fig. 6. Schematic of the simple theory of light interference.

For the arbitrary ras, we need anly consider the physical dfstances through $a 1 \mathrm{r}$, glass, and gas from point $A$ to $B$ and gu!t: ply each length by the approprlate refractive index. The fiducial ray for the microsphere is the x-axis ray, which passes through the least amount of glass. We assume that a glaes epacer has been inserted in the reference arm of the interferometer to bring the optical path difference between the reference arm $x$-axis ray and microsphere $x$-axis ray to zero. We can then 1gnore the reference rays, with which the Interference in fact occurs, and consider only the relation of the microsphere rays.

The aptical path length of the $x$-axis microsphere ray, $s_{0}$, from start to $f$ inish, is

$$
S_{C}=4\left[N^{\prime \prime} I+N^{\prime \prime}(1-1)\right] .
$$

The corresponding optical pach length of the arbitrary ray, S, of planar rajlus $P$ is

$$
\begin{aligned}
S= & 4\left(\left[1-\left(1-P^{2}\right)^{\frac{2}{2}}\right]\right. \\
& +N \cdot\left\{\left(1-P^{2}\right)^{4 / 2}-\left[(1-L)^{2}-P^{2}\right]^{\frac{2}{2}}\right\}
\end{aligned}
$$

$$
\left.+N^{\prime \prime}\left[(1-I)^{2}-P^{2}\right]^{\frac{1}{2}}\right)
$$

The two microsphere rays will rea, $h$ the finish line at different times, since the arbitrary ray has been slowed down by passage through more glass. The phase difference between the two rays is obtained by subtrac:1ng Eq. (7) from Eq. (B). For physica: simplictey, we also expand the square-root terms to a two-term binomlal series expression as followe:

$\left(1-P^{2}\right)^{\frac{1}{5}}=1-\frac{P^{2}}{2} \quad$ for $P \ll 1$

By carrying out the Indicated operations, we obtaln the optical-path-1ength difference $\Delta S$ :

$\Delta S=\frac{2 P^{2}}{(1-L)}\left(N^{\prime}-1\right) L-\left(N^{\prime \prime}-1\right)$. 
If the optical-path-length difference In Eq. (10) Is multiplied by the true outer radius $\tau_{1}$, the resulting length may be cornpared with the wavelength of the observing 1Ight. Constructive Interference at the arbitrary planar radius $P$ will occur if

$$
\Delta S=\frac{m \lambda}{\tau_{1}}
$$

where $\lambda$ is the ravelength of th- observing light and a is an integer. Hence we expect a gerles of interference rings, representIng different orders m. Equation (10) shows that the opticaI-path-length difference Increases parabollcally, so that higher order interierence fringes become more crowded as one progresses outward from the center of the microsphere. Since Eq. (10) is derived from an approsination in whtch $P \ll 1$, ore taight expect the exact $\Delta S$ to rise even more steeply. Physically, however, one cannot display a fringe In less than a half-wavelength of planar ratlus (i.e., $\partial \Delta S / \partial P<1)$. One expects the fringes to possibly fade out neer the edge. The refractive ray-trace program 5,67 5telds an optlcal-path-length difference is that rises with the planar radius $P$ more steeply than the parabolic function of Eq. (10). Refraction also reduces the glass paths and Increases the airmas dism cances, so that the code-predicted behavlor is better described uy the form

$\Delta S=\frac{1.6 P^{2}}{(1-L)}\left[\left(\mathrm{N}^{+}-1\right) L-1.4\left(\mathrm{~N}^{\mathrm{N}}-1\right)\right]$.

Equation (i2) shows that the presence oi DT gas inside the microsphere uill lower the optical path difference. This is because the arbitrary ray passes through less DT gas than does the $x$-axis ray and hence galns in time. A cyplcal laser target is of glass with refractive Index 1.50 and has an L value of 0.02 . If the microsphere were filled to $10^{3}$ noles $/ \mathrm{m}^{3}(2.5 \mathrm{MPa}$ or 360 psi at $390 \mathrm{~K})$, the $\mathrm{DT}$ gas refractive index, $\mathbf{N}^{\prime \prime}$, according te E, s. (1) and (2), would be 1.00315. In Eq. (12), the second term is almost the size of the iirst. The total optical path is reduced by almost hali, and the fringes are pushed outward on the tace of the microsphere. If DT gas could be added without breaking the microsphere, the eventual result would be the condition

$$
\left(N^{\prime}-1\right) L=1.4\left(N^{\prime \prime}-1\right),
$$

In which no iringes are obtained because the glass path and the DT patb just eancel one another. For the microsphere example whove, this would occur for a pressure of about 6 MPa, whlch would probably break the thst walls.

\section{'rterfernmetry on Fromen GT Micrumberes}

It is interesting to cons dder the correspond $2 \pi$ b light interterence patern tor a froxen hollow bT nicrosphere. it $4.2 \mathrm{k}$, the refractive Index of the walls, $N$ ', Is, by the eselonte of Table ?, onIy 1.17. The vapor pressure at $4.2 K 1$ s estbmated tu be about $2.4 \times 10^{-10} \mathrm{~Pa}\left(1.8 \times 10^{-12}\right.$ Torf $^{63}$ so that the internai gas refractive index it 1.000. The term (1' - 1) in Eq. (12) is one-chird the magnicude of chac of glass, 
and the fringes will be at least ( 3$)^{\frac{1}{2}}$ farther out for the same dimensions. Only a fairly thick microsphere will show even a first fringe. For a diameter of $100 \mathrm{im}$ and 0.55-2m light, the thickness I must be greater than $0.024 \mu$ to accumulate even one half-wavelength of optical-path-length difference.

At the triple point, liquid DT has an estimaced refractive index $\mathrm{N}^{*}$ of 1.14 ( Table 2) and an estimated equilfbrium vapor pressure of $1.94 \times 10^{4} \mathrm{~Pa}$ (145.7 Torr). ${ }^{45}$ The vapor pressure yields a density of 119 noles $/ \mathrm{m}^{3}$ and an estimated refractive index $N^{\prime \prime}$ of 1.00037. Equation (12), corrected for the equilibrium atmosphere outside the microsphere as well, becomes

$$
\Delta S=\frac{1.6 P^{2}}{(1-L)}\left(N^{\prime}-N^{\prime \prime}\right) L .
$$

The optical-path-length differenre is now only $28 \%$ that of the glass microiphere; the fringes, if any, move out a little further. The path-subtraction effect of Eq. (13) is reduced in importance by roughly the factor $L$. This is because the sum of the DT gas oucside and inside results in an almust constant path-length correction to 25 .
It 1s apparent that the interferometry of small DT microspheres can be hampered by the very owall difference in predicted refractfve index between the IIquid and the solid. Higher laser energies will lead to the use of larger microspheres, which will be easier to examine. The two-arm method of Interference may not be practical at low temperatures for a moving-target microscope. Single-arm Interferometers exist and will be more atable in a cryostat. The use of multiple reflections to butld up optical path-leagth difference in the Fabry-Pérot etalon may be useful. ${ }^{64}$ Also of interest is the refractive method of Reedy of this Laboratory, ${ }^{65,66}$ in which parallel 1ight is refracted by the microsphere and collected by a lens with a known, stopped aperture. A lack ring la seen at the microsphere edge, and light Interference is not required. However, the aingle pass of the light through the low-Index solld DT will not produce refraction at very large angles, and a sensitivity problem will also appear.

Acknowledgment. We wish to thank $\mathrm{J}$. Emett of LLL for his continuing interest In the properties of cryogenic DT.

\section{References}

1. J. Nucko11s, L. Wood, A. Thiessen, and G. 21 mmerman, Nature 239, 193 (1972).

2. J. Nuckalls, J. Emmett, and L. Wood, Ehysice Taday 26(8), 46 (Auguet 1973).

3. J. Emmett, J. Nucko11s, and L. Wood, Sclentific American 230(6), 24 (June 1974).

4. H. C. Souers, R. T. Tsugawa, and R. R. Stone, Rev. Sc1. Ingtr. 46, 682 (1975).

5. R. R. Stone, D. W. Gregg, and P. C. Souera, J. Appl. Phye. 46, 2693 (1975).

6. P. C. Souers, R. T. Tugawi, and R. R. Stone, Fabrlcation of the Glass Microbubble Laser Target, Laurence Iivermore Laboratory, Rept. UCPI 51609 (1974). 
7. P. C. Souers, R. G. Hickman, W. 2. Wade, and R. T. Tsugawa, A Simple Model of D2-DT-T2 Equilibrium at Cryogenic Temperatures, Lawrence Livermore Laboratory, Rept. UCRL 51681 (1974).

8. P. C. Souers, R. G. Hickman, W. Z. Wade, and R. T. Tsugawa, Estimated Infrared Spectra of Cryogenic $D_{2}-D T-T_{2}$, Lawrence LIvermore Laboratory, Rept. UCRL-51674 $(1974)$.

9. C. K. Briggs, R. G. Hickman, R. T. Tsugawa, and P. C. Souers, Estloated V1scosity, Surface Tension and Density of Liquid DT from the Triple Point to $25 \mathrm{~K}$, Lawrence Livermore Laboratory, Rept. UCRL-51827 (1975).

10. D. E. Diller, J. Chem. Phys. 49, 3096 (1968).

11. G. E. Childs and D. E. Dillex, Adv, Cry. E..B. 15, 65 (1969).

12. H. M. Roder, G. E. Ch1lds, R. D. McCarty, and P. E. Angerhofer, Survey of the Propertieg of the Bydrogen Isotopes Below Thetr Crictcal Temperature, National Bureas of Standards Technical Note 641 (August 1973), Section 7-1.

13. T. Larsen, Z. Physik 100,543 (1936).

14. R. Prydz, The Thermodynamic Propertieg of Deutertum, National Bureau of Standards, Rept. 9276 (1967).

15. H. E. Johns and J. O. W11he1m, Can. J. Res. 1.5, 101 (1937).

16. R. J. Corruccin1, Refractive Index and Dispersion of Ltquid $\mathrm{H}_{2}$, National Bureau of Standards Technical \$ote 323 (1965).

17. A. V. Belonogov and U. M. Gorbunkov, Instruments and Experimental Techniques, No. 3, 664 (May-June, 1965).

18. F. A. Jenkins and H. E. White, Fundamentals of Optics, 3rd ed. McGraw-H111, New York, 1967), p. 258 .

19. C. P. Abbisa, C. M. Krobler, R. K. Teague, and C. J. Pings, J. Chem Phys. 42, 4145 (1965).

20. E. R. Dobbs, B. F. Flggins, G. O. Jones, D. C. Plercey, and I. P. Riley, Nature $198,483(1956)$.

21. A. J. Eatwell and G, O, Jones, PhIl, Mag, 10, 1059 (1964).

22, H. E. Watson and K. L. Ramaswamy, Froc. Roy. Soc. (London) A156, 144 (1936).

23. F. A. Jenkino and H. E. White, Fundamentals of Optics, 3rd ed. (McGraw-HI11, New York, 1967), P. 481 .

24. Reference 12, Sections 2,1-2,2.

25. H. D. Megaw, PhI1. Mag. 28. 129 (1939).

26. H. W. Woolley, R. B. Scott, and F, G. Brickwedde, J. Res, Net1, Bur. Std, 41, 379-475 (1948).

27. R. F, Dwyer, G. A, Cook, O. E. Berwalit, and H. E. Nevins, J. Chem. Phys. 43, 801 (1965).

28. G, A, Cook, R. F. Dwyer, D, E. Berwaldt, and H. E. Nevins, J. Chen. Phys, 43, 1313 (1965). 
29. W. J. Moore, Physical Chemistry, 3rd ed. (Prentlce-Hall, Englewood C11ffs, N.J., 1963), p. 104 .

30. J. Jarvis, D. Ramm, and H. Meyer, Phys. Rev. Letcere 18, 119 (1967).

31. V. S. Kogan, A. S. Bulatov, and L. F. Yakimenko, Soviet Physies--JETP 19, 107 (1964).

32. R. L. Mills and A. F. Schuch, Phys. Rev. Letrers 15, 722 (1965).

33. A. E. Curzon and A. J. Mascall, Br1t. J. Appl. Phys. 16, 1301 (1965).

34. O. Bostanjoglo and R. Klelnschm1dt, J. Chem. Phys, 46, 2004 (1967),

35. A. F. Schuch, R. L. M111s, and D. A. Depat1e, Phys. Rey. 165, 1032 (1968).

36. A. S. Bulatov and V. S. Kogan, Soviet Phyg1es-JETP 27, 220 (1968).

37. K. F. Mucker, S. Talhouk, P. X. Hurris, D. White, and R. A. Erickson, Phys. Rev. Letters 15,586 (1965).

38. A. F. Schuch and R. L. M11ls, Phys, Rev, Letcers 16, 616 (1966).

39. K. F. Mucker, P. Y. Harr1s, and D. Wh1te, J. Chem. Phys, 49, 1922 (1968).

40. V. S. Kogan, B. G. Lazarev, and R. F. Bulatova, Sov1et Physics--JETP 10, 485 (1960).

41. C. Kittel, Intraduction to Sol1d Stace Physics, 2nd ed. (Ktley, New York 1960), p. 35 .

42. IbId., p. 26.

43. G. Ahlers, Some Prupertles of Solld Hydrogen at Spall Molar Volumes, Lawrence Rad1ation Laboratory, Rept. UCRL-10757 (1963).

44. Reference 12, Table 3-1.

45. Reference 12, Section 11.

46. C. A. Foster, C. D. Hendricks, and R. J. Tumbull, Appl. Phys. Letters 26, 580 (1975).

47. Reference 12, Sect ton 4.

48. R. K. H111 and B. W. A. K1cketson, Ph11 Hag. 45. 727 (1954).

49. R. L. M111e, A. F. Schuch, and D. A. Depat1e, Phys. Rev. Letters 17, 1131 (1966).

50. K. W. Hill, B. W. A. RIcketson, and F. Simon, In Confërence de Phyeique des Banges Tesperatures, Paris, 1955 (Inetitute Internationel de Fro1d, Par1s, 1955), No. 76, p. 317 , cited In Ref. 3 .

51. M. Cloucer and H. P. Gush, Phye. Rev. Leteers 15, 200 (1965).

52. F. Relf and E. K. Purcell, Phye. Rev. 91, 63 (1953).

53. A. B. HarriA, 3. Appl. Phys. 42, 1574 (1971).

54, C. F. Coll and A, B, Harrif, Phys, Rev, 4B, 2781 (1971).

55. L. I. Ametutz, H. Neyer, S. M. Hyers, and D. C. Rover, Phya. Rev. 182, 589 (1969). 
56. W. N. Hardy, I. E. Silvera, and J. P. McTague, Phys. Rev. Letters 22, 297 (1969).

57. S. C. Durana and J. P. MeTague, Phys. Rev. Letters 31, 990 (1973).

58. E. W. Albers, P. Hartech, and R. R. Reeves, J. Amer. Chen, Soc. 86, 204 (1964).

59. R. Frauenfelder, E. Hefnrich, and J. B. Ol1n, Helv. Phys. Acte 38, 279 (1965).

60. R. R. Stone, Measurement of Laser Fuston Capsules Using the Interferometer Method of Excess Fractions, Lawrence LAvermore Laboratory, Rept. UCRL-51788 (1975).

61. B. Weinatein, Lawrence Livermore Laboratory, private communication, 1975.

62. R. R. Stone and P. C. Souers, paper to be published.

63. P. C. Souers, paper to be published.

64. J. Dyson, Interferometry as a Meaguring Tool (Machinery Publishing Co., London, 1970), Pp. 96-98, 103-111.

65. R. P. Reedy, Nondestruct1ve Testing of Laser Targets, Lasrence LIverwore Laboratory, Rept, UCRL-51630 (1974).

66. R. P. Reedy, paper to be published 1n the Joumal of Applied Physics.

WEC/nus 